\title{
AS CONDIÇÕES DA AÇÃO NA REFORMA PARCIAL DO CÓDIGO DE PROCESSO PENAL
}

\author{
Guilherme Brenner Lucchesi* \\ "O uso do cachimbo faz a boca torta". \\ - Provérbio popular brasileiro
}

SUMÁRIO: 1 INTRODUÇÃO. 2 BREVES APONTAMENTOS SOBRE A “TEORIA GERAL DO PROCESSO". 3 CRÍTICA À CONCEPÇÃO TRADICIONAL DAS CONDIÇÕES DA AÇÃO NO PROCESSO PENAL. 3.1 POSSIBILIDADE JURÍDICA DO PEDIDO. 3.2 INTERESSE DE AGIR. 3.3 LEGITIMAÇÃO AD CAUSUM. 4 A CONCEPÇÃO CRÍTICA DAS CONDIÇÕES DA AÇÃO COMPATÍVEL COM O PROCESSO PENAL BRASILEIRO. 4.1 TIPICIDADE APARENTE. 4.2 PUNIBILIDAdE CONCRETA. 4.3 LEGITIMIDAdE DE PARTE. 4.4 LASTRO MÍNIMO INFORMATIVO (“JUSTA CAUSA"). 5 CONCLUSÃO.

\section{RESUMO}

Busca o presente trabalho tecer alguns breves comentários sobre o atual estado das condições da ação penal após a reforma do Código de Processo Penal pela Lei n. 11.719/08, devido à lacuna deixada pela supressão do artigo 43 do referido diploma legal, bem como pela lacônica redação do artigo 395. O presente trabalho se alinha ao segmento doutrinário que nega a "teoria geral do processo", ao passo em que busca a construção de uma Teoria Geral do Direito Processual Penal. Defende, portanto, a inexistência das condições da ação da maneira conforme concebidas pela doutrina monista, ao passo que as afirma enquanto as condições que historicamente obstaram o recebimento da ação penal, a saber, tipicidade aparente, punibilidade concreta, legitimidade de parte e justa causa.

Palavras-chave: Condições da ação; tipicidade aparente; punibilidade concreta; legitimidade de parte; justa causa.

* Mestrando em Direito pela Cornell University Law School. Pós-graduando em Direito Penal e Criminologia pelo Instituto de Criminologia e Política Criminal. Advogado criminalista. Bacharel em Direito das Relações Sociais pela Universidade Federal do Paraná em 2008. E-mail: guibrenner@gmail.com 


\begin{abstract}
The purpose of this study is to briefly comment on the current state of the conditions of prosecution after the reform of the Brazilian Code of Criminal Procedure by Law $11,719 / 2008$, due to the gap caused by the suppression of Article 43 of said law, and the laconic wording of Article 395. This academic endeavor is aligned with the segment of legal doctrine which denies the "general theory of procedure", and sets itself with those who believe in the necessity of developing a General Theory of Penal Procedural Law. It defends, therefore, that the conditions of action as designed by the monistic doctrine are inexistent, and that these should be conceived as those conditions that have historically hindered the inception of criminal proceeding, namely, apparent vagueness, concrete punishableness, standing and just (probable) cause.
\end{abstract}

\title{
1 INTRODUÇÃO
}

No ano de 2008 o Código de Processo Penal brasileiro sofreu uma série de minirreformas, que acabaram por alterar as matérias referentes a $\operatorname{provas}^{1}$, ao procedimento dos crimes dolosos contra a vida ${ }^{2}$, e aos procedimentos comum ordinário e sumário ${ }^{3}$, esta, quiçá, a mais importante delas.

Uma das muitas alterações do Código de Processo Penal pela Lei n. 11.719/08 ocorreu com a supressão do artigo 43, utilizado para extrair as condições para o recebimento da ação penal em seu juízo de admissibilidade, e a modificação da redação do artigo 395, que apenas se refere às condições da ação de maneira genérica e lacônica, transferindo à jurisprudência e especialmente à doutrina a árdua tarefa de definir tais condições.

É este o objetivo do presente estudo: traçar comentários acerca da definição das condições da ação penal com a reforma do Código de Processo Penal.

\footnotetext{
${ }^{1}$ Lei n. 11.690, de 9 de junho de 2008.

${ }^{2}$ Lei n. 11.689, de 9 de junho de 2008.

${ }^{3}$ Lei n. 11.719, de 20 de junho de 2008.
} 
Para tanto, será necessário primeiramente desconstruir a pretensa "teoria geral do processo", utilizada para a aplicação equivocada de institutos próprios do processo civil ao processo penal, pois acredita-se na necessidade de se erguer uma Teoria Geral do Direito Processual Penal fundada em institutos e categorias próprios à realidade do Processo Penal.

Em seguida, analisar-se-ão as condições da ação conforme defendidas pela teoria monista, apresentando os motivos para sua inadequação ao Processo Penal, para, ao final, demonstrar quais são as condições da ação penal de acordo com a Lei n. $11.719 / 08$.

\section{BREVES APONTAMENTOS SOBRE A "TEORIA GERAL DO PROCESSO"}

Para tratar propriamente das condições da ação na nova redação do Código de Processo Penal é preciso, antes, se delinear alguns comentários acerca do posicionamento doutrinário adotado na redação do presente trabalho no que diz respeito ao conteúdo do Processo Penal.

Muitos autores brasileiros ainda hoje acreditam na existência de uma "teoria geral do processo". Segundo esta teoria, todas as espécies de processo teriam elementos e institutos comuns, pois teriam um mesmo conteúdo. Desta forma, o processo civil e o processo penal, em que pese terem suas especificidades, teriam o mesmo conteúdo, portanto, compartilhariam conceitos e institutos.

Esta concepção teve origem no século passado, quando Francesco Carnelutti desenvolveu seu conceito de lide, originariamente voltado ao processo civil, mas cuja aplicação também estendeu a todos os processos jurisdicionais, inclusive ao processo

4 MARQUES, José Frederico. Elementos de direito processual penal. Campinas: Bookseller, 1997. v. 2; CINTRA, Antonio Carlos de Araújo; GRINOVER, Ada Pelegrini; DINAMARCO, Cândido Rangel. Teoria geral do processo. 18. ed. São Paulo: Malheiros, 2002, p. 48-49. 
penal, desta forma dando origem à "teoria geral do processo". 5

A formulação de Carnelutti sofreu diversas críticas ao longo dos anos, não apenas dos processualistas penais, que acreditavam não ser o conceito de lide capaz de representar o conteúdo do processo penal, mas também de processualistas civis, os chamados objetivistas, que faziam da atuação do direito objetivo o escopo elementar da função jurisdicional. A primeira das importantes críticas que o conceito de lide recebeu, e que possui relevância no âmbito do processo penal, ocorreu durante polêmica entre Carnelutti e o processualista civil Piero Calamandrei.

Segundo Calamandrei, a jurisdição atua para efetivar um controle da pretensão estatal de aplicação da pena que não pode ser efetivada na esfera administrativa. ${ }^{6}$ Desta forma, é indiferente à jurisdição se há ou não conflito; ela vai atuar para decidir se deve ser aplicada ou não a sanção penal. Para ele, a introdução de um conflito intersubjetivo de interesses para sustentar o conteúdo do processo penal parecia uma heresia. ${ }^{7}$

Além disto, afirma a inexistência de um conflito de interesses (ainda que presumido) porque mesmo um eventual acordo entre as partes em conflito teria total irrelevância no processo.

Desta forma, segundo Calamandrei, "o conceito de lide não é utilizável como elemento dispositivo da função jurisdicional, pela simples razão que os interesses, ao regulamento dos quais é preordenado a necessária intervenção do juiz, não são disponíveis àqueles que figuram como partes do processo". 8

${ }^{5}$ MIRANDA COUTINHO, Jacinto Nelson de. A lide e o conteúdo do processo penal. Curitiba: Juruá, 1989, p. 21.

${ }^{6}$ Ibidem, p. 41-42.

${ }^{7}$ Ibidem, p. 42.

${ }^{8}$ CALAMANDREI, Piero. Il concetto di "lite" nel pensiero di Francesco Carnelutti. Rivista di Diritto Processuale Civile, Padova, v. 5, p. 1, p. 17, 1928: “(...) il concetto di lite non è utilizzabile come elemento distintivo della funcione giuridicionale, per la semplice ragione che glise interessi, al regolamento dei quali è preordinato il necessario intervento del giudice, non sono disponibili da coloro che figurano como parti nel processo". Tradução de Jacinto Nelson de MIRANDA COUTINHO (A lide e o conteúdo do processo penal, p. 43). 
É importante ressalvar, todavia, que as críticas ao conceito de lide por Calamandrei se deram no âmbito do chamado "processo civil inquisitório", porém seus apontamentos também se prestam ao processo penal, por ser este inquisitório por excelência. ${ }^{9}$

Outro que polemizou a definição de lide, porém como conteúdo do processo penal, foi o processualista penal Giulio Paoli. Ao criticar a lide no processo penal, Paoli apresenta três proposições:

$1^{\circ}$ ) se no processo penal fosse possível encontrar-se o critério da lide, como elemento essencial e característico da função jurisdicional, essa só poderia ser entre Ministério Público e imputado; $2^{\circ}$ ) mas nenhuma lide, no sentido aqui estabelecido, existe entre Ministério Público e imputado; $3^{\circ}$ ) muito menos entre imputado e parte lesada. $^{10}$

Para Paoli, se houvesse um conflito de interesses no processo penal, este seria entre aquele que deduz a pretensão em juízo (o Ministério Público) e quem a contesta (o acusado), todavia o Estado, representado pelo Ministério Público no processo, tem interesse na condenação de culpados e na absolvição de inocentes, e, por isso, dada a decisão jurisdicional determinando a culpa ou a inocência do imputado, o Estado sempre terá seu interesse atendido, e, desta forma, inexistiria conflito entre ele e a parte imputada. ${ }^{11}$

Ademais, defende a inexistência de um conflito de interesses entre imputado e parte lesada, utilizando-se de um exemplo de lide entre ladrão e roubado:

${ }^{9}$ Vide MIRANDA COUTINHO, J. N. O papel do novo juiz no processo penal. In: (Coord.). Crítica à teoria geral do direito processual penal. Rio de Janeiro: Renovar, 2001. p. $\overline{3-55}$.

${ }^{10}$ PAOLI, Giulio. La nozione di lite nel processo penale. Rivista di Diritto Processuale Civile, Padova, v. 7, p. 1, p. 65,1930 : “ $1^{\circ}$ ) se nel processo penale potesse ricontrarsi il criterio di lite, come elemento essenziale e caratteristico alla funzione giurisdizionale, questa non potrebbe essere Che tra p. m. e imputato; $2^{\circ}$ ) ma lite, nel senso suddetto, non v'è tra p. m. e imputato; $3^{\circ}$ ) molto meno v'è tra imputato e parte lesa". Tradução de Jacinto Nelson de MIRANDA COUTINHO (A lide e o conteúdo do processo penal, p. 55).

${ }^{11}$ MIRANDA COUTINHO. A lide e o conteúdo do processo penal ..., p. 56. 
(...) porque ele (parte lesada) não é sujeito nem da relação punitiva, nem da ação penal; porque ele pode ter sido completamente ressarcido; porque pode ter sido perdoado completamente; porque, em suma, o processo penal subsiste independentemente da mais ampla eliminação do conflito entre roubado e ladrão; porque, enfim, o imputado pode não ser o ladrão (e portanto não haver lesão de interesse por ele produzida) e o roubado pode reconhecer que o imputado não é o ladrão (e portanto não haver contestação na espécie). ${ }^{12}$

Para Paoli, o interesse ofendido seria o da sociedade, pois só isso poderia explicar os delitos de automutilação e maus tratos de animais próprios, por exemplo. Ao definir a sociedade como sujeito passivo, Paoli então remete a passividade ao Estado, enquanto exprime a personalidade jurídica da sociedade, e, portanto, ao Ministério Público, enquanto representa o Estado. ${ }^{13}$

Das polêmicas acerca do conteúdo do processo penal, a mais conclusiva foi a tida com Francesco Invrea. ${ }^{14}$ Segundo Invrea, é possível que haja um processo penal sem que haja lide:

Tizio (que eu não conheço nem mesmo de vista), é imputado (sob denúncia de um terceiro) de haver furtado durante a noite poucos cachos de uva de um vinha minha. Eu jamais levantei contra Tizio antes do furto alguma pretensão de inviolabilidade da minha propriedade; depois de ocorrido o furto eu nunca imaginei levantar contra ele pretensão alguma, também porque (das informações prestadas) me convenci que ele era inocente; em audiência declaro que o considero inocente; o juiz, conforme as conclusões do Ministério Público, absolve Tizio por não ter cometido o crime. ${ }^{15}$

${ }^{12}$ PAOLI, op. cit., p. 69: “(...) perchè egli non è soggetto nè del rapporto punitivo, nè dell'azione penale; perchè può essere stato immediatamente risarcito; perchè può avere completamente perdonato; perchè, insomma, il processo penale sussiste indipendentemente da ogni più ampia eliminazione di constrasto fra derubato e ladro; perchè, infine, l'imputato può non essere il ladro (e quindi non v'è lesione di interesse da lui compiuta) e il derubato può riconescere che l'imputato non è il ladro (e quindi non v'è contestazione di sorta)". Tradução de Jacinto Nelson de MIRANDA COUTINHO (A lide e o conteúdo do processo penal, p. 60).

${ }^{13}$ MIRANDA COUTINHO. A lide e o conteúdo do processo penal ..., p. 60.

${ }^{14}$ Ibidem, p. 65.

15 INVREA, Franceso. La servitù del giudicato. Rivista di Diritto Processuale Civile, Padova, v. 7, p. 1, p. 226, 1930: "Tizio (che io non conosco neppure di vista), è imputato (su denuncia de um terzo) di avermi rubato pochi grappoli d'uva di notte in uma mia vigna. Io non há mai contro Tizio elevato prima del furto alcuna pretesa all'inviolabilità della mia proprietà; dopo avvenuto il furto io non mi sono mai sognato di elevare contro di leui pretesa alcuna, anche perché (da 
Desta forma, defendeu que deve ser desconsiderada a lide como pressuposto do processo, pois há sentenças que não advêm para compô-la.

Outra crítica feita à formulação carneluttiana é que, por seu caráter público, a pena não pode ser incluída na pretensão do particular, pois não pode formar seu objeto, cabendo a ele apenas ingressar no processo penal como parte civil, para requerer indenização posterior na Justiça cível. ${ }^{16}$ Assim, não haveria pretensão nem do particular, muito menos do Ministério Público, pois a condenação poderia advir até mesmo contra a sua vontade (devido à inquisitoriedade do processo penal italiano). Segundo INVREA, "ao nosso processo penal é portanto estranho absolutamente o conceito de lide". ${ }^{17}$

Com a crítica de Invrea, Carnelutti se deu conta da possibilidade do processo penal existir sem manifestação de pretensão da parte ofendida. Todavia, para refutar as críticas, ele afirmou que um terceiro (como o representante, o substituto processual ou o Ministério Público) poderia manifestar em juízo sua pretensão, até porque se trataria de um interesse público. ${ }^{18} \mathrm{O}$ Ministério Público não figuraria, então, como um sujeito material da lide, mas como um sujeito do processo por meio do elemento formal pretensão, "enquanto, propondo a demanda penal, afirma o direito lesado pelo crime". ${ }^{19}$

informazione assunte) mi sono persuaso che egli è innocente; all'udienza dichiaro di ritenerlo innocente; il pretore, su conformi conclusioni del P. M., assolve Tizio per non avere comesso il reato". Tradução de Clara Maria Roman BORGES (Jurisdição e normalização: Uma análise foucaultiana da jurisdição penal, pp. 29-30).

${ }^{16}$ MIRANDA COUTINHO. A lide e o conteúdo do processo penal ..., p. 69-70.

${ }^{17}$ INVREA, op. cit., p. 227: "Al nostro proceso penale è quindi estraneo assolutamente il concetto di lite". Tradução de Jacinto Nelson de MIRANDA COUTINHO (A lide e o conteúdo do processo penal, p. 70).

${ }^{18}$ MIRANDA COUTINHO. A lide e o conteúdo do processo penal ..., p. 72.

${ }^{19}$ CARNELUTTI, Francesco. Ancora sulla lite nel processo penale (Postilla). Rivista di Diritto Processuale Civile, Padova, v. 7, p. 1, p. 246, 1930: “(...) in quanto, proponendo La domanda penale, afferma il diritto leso dal reato". Tradução de Jacinto Nelson de MIRANDA COUTINHO (A lide e o conteúdo do processo penal, p. 73). 
Invrea aproveitou a fraqueza da réplica de Carnelutti e a treplicou, desta forma aniquilando a tentativa de se demonstrar que no processo penal a pretensão (pressuposto inafastável da lide) é manifestada pelo Ministério Público, afirmando um direito da vítima, lesada pelo crime. ${ }^{20}$

Como é insustentável a lide sem pretensão, Carnelutti tratou de a deslocar do ofendido ao Ministério Público, todavia aquilo por ele aduzido em juízo em nada está vinculado à suposta pretensão do ofendido, tanto que pode requerer pela absolvição, teoricamente contrariando o interesse da parte ofendida. ${ }^{21} \mathrm{E}$, mesmo assim, o juiz não é obrigado a condenar, porque a manifestação do Ministério Público não o vincula. Invrea terminou sua tréplica sustentando que o processo se faz para acertar se se deve ou não impor ao imputado a servidão (autoridade) do julgado, reconhecendo o direito (ou poder) do Estado aplicar uma pena determinada. ${ }^{22}$

Após a polêmica com Invrea, que foi a última das polêmicas de Carnelutti sobre o conceito de lide e sua adoção como conteúdo do processo penal, e que resultou na demonstração da imprestabilidade do conceito para o processo penal, o próprio Carnelutti passou a negar sua própria tese, fazendo uso, para tanto, de muitos dos argumentos por ele próprio combatidos.

Posteriormente, o conceito de lide foi "aperfeiçoado", entre outros, por Giovanni $\mathrm{LEONE}^{23}$, cujo conceito de lide penal é utilizado até hoje, dado respeitar as especificidades do processo penal, em que pese manter-se baseado em conceitos eminentemente privados, tais como "interesse" e "pretensão". 24 Fundado neste

\footnotetext{
${ }^{20}$ MIRANDA COUTINHO. A lide e o conteúdo do processo penal ..., p. 73-74.

${ }^{21}$ Ibidem, p. 74.

${ }^{22}$ Ibidem, p. 75.

${ }^{23}$ Ibidem, p. 91-98.

24 Já ensinava o próprio CARNELUTTI que o interesse "é uma relação entre uma necessidade do homem e um quid ato para satisfazê-la (...); uma situação favorável à satisfação de uma necessidade". CARNELUTTI, F. Lezioni di diritto processuale civile. Padova: Cedam, 1926. v. 1, p. 3: "La nozione fondamentale per lo studio del diritto è la nozione di interesse. Questa è a sua volta strettamente legata alla nozione di bisogno; interesse è appunto un rapporto tra un bisogno dell'uomo e un quid atto a sodisfarlo. Più precisamente l'interesse si definisce come uma situazione favorevole al sodisfacimento di um bisogno". Tradução de Jacinto Nelson de MIRANDA COUTINHO
} 
conceito de lide penal, em que haveria um conflito imanente e indisponível de interesses entre o Estado e seu jus puniendi e o autor do delito e seu status libertatis, ${ }^{25}$ é que se erigiu a "teoria geral do processo" entre segmentos da doutrina brasileira. ${ }^{26}$

Acredita-se, todavia, que não existe, nem pode existir, uma "teoria geral do processo", pois seus desdobramentos não condizem com a realidade processual penal brasileira, além de possuir fundamentos eminentemente privados (pretensão e conflito de interesses). Ocorre que, por mais que o conceito de lide penal de LEONE seja diverso da lide carneluttiana, as bases que sustentam ambos os conceitos são as mesmas.

O conflito imanente de interesses não deixa de ser um conflito de interesses, o que as polêmicas de Carnelutti com Calamandrei, Paoli e Invrea já há muito demonstraram não poder servir como conteúdo do processo penal. Além disso, arremata Franco Cordero: "O fenômeno penalístico está todo aqui: falar de 'relação penal', de 'direito de punir', de 'pretensão punitiva', de 'direito de liberdade' do imputado e de um conflito entre um e outro, significa triturar palavras em grande parte privadas de significado". ${ }^{27}$

(A lide e o conteúdo do processo penal, p. 25)], e que "se interesse é a situação de um homem favorável à satisfação de uma necessidade, essa situação se verifica portanto respectivamente a um bem: homem e bem são os dois extremos da relação, a que nós chamamos interesse" [CARNELUTTI, op. cit., loc. cit.: "Si interesse è la situazione di um uomo favorevole al sodisfacimento di um bisogno, questa situazione si verifica dunque rispetto a um bene: uomo $e$ bene sono i due termini del rapporto, che noi chiamiamo interesse". Tradução de Jacinto Nelson de MIRANDA COUTINHO (A lide e o conteúdo do processo penal, p. 25)], portanto "sujeito do interesse é o homem; o objeto do interesse é o bem". Ibidem, loc. cit.: "Subbieto dell'interesse è l'uomo; obbietto dell'interesse è il bene". Tradução de Jacinto Nelson de MIRANDA COUTINHO (A lide e o conteúdo do processo penal, p. 26)]. Ademais, afirma CARNELUTTI que há pretensão "quando uma das partes afirma contra uma outra que lhe compete, em um conflito de interesses, a produção do direito". Ibidem, p. 299: "Quando uma delle parti affirma contro um'altra che le compete in um conflitto di interesi la protezione del diritto, questa propone contra l'altra uma pretesa". Tradução de Jacinto Nelson de MIRANDA COUTINHO (A lide e o conteúdo do processo penal, p. 29)].

\footnotetext{
${ }^{25}$ MIRANDA COUTINHO. A lide e o conteúdo do processo penal ..., p. 121.

${ }^{26}$ CINTRA; DINAMARCO; GRINOVER, op. cit., p. 116.
}

${ }^{27}$ CORDERO, Franco. Procedura penale. Milano: Giuffré, 1987, p. 11: "Il fenomeno penalistico è tutto qui: parlare di «rapporto penale», di «diritto di punire», di «pretesa punitiva», di «diritto di libertà» dell'imputato e di um conflitto tra l'uno e l'altro, significa macinare parole in gran 
Desta forma, o presente trabalho se alinha à corrente doutrinária que acredita na construção de uma Teoria Geral do Processo Penal, com fundamentos, conceitos e institutos próprios, tendo como base um conteúdo diverso da lide. Para tanto, acreditase ser o conteúdo do processo penal um caso penal ${ }^{28}$, e seu objeto o acertamento deste caso $^{29}$, pois "o processo penal serve a verificar se uma pessoa deve ser punida"30, “isto é, no fundo, o processo é um meio utilizado pela jurisdição para fazer o acertamento do fato". 31 Tal significante, por não estar comprometido com outros significados relevantes ${ }^{32}$, serve perfeitamente ao objetivo pretendido, que é a construção de um processo penal despido das vestimentas do processo civil, ${ }^{33}$ isto é, autônomo não apenas didaticamente, mas também cientificamente.

Embora a construção de uma Teoria Geral do Processo Penal exija um repensar geral do processo penal já construído, é evidente que isso não acarreta, todavia, na negativa de tudo o que já fora produzido neste âmbito. "Devemos trabalhar sem preconceitos e utilizar tudo aquilo de realmente útil, venha do processo civil ou de quem quer que seja. Só não cabe malabarismo lingüístico, contorcionismos para uma adaptação impossível'. 34

Neste âmbito, ao se ponderar acerca das condições da ação nos itens abaixo, se busca de alguma forma contribuir com o erigir de uma Teoria Geral do Direito

parte prive di significato". Tradução de Jacinto Nelson de MIRANDA COUTINHO (A lide e o conteúdo do processo penal, p. 107).

${ }^{28}$ Segundo MIRANDA COUTINHO (A lide e o conteúdo do processo penal ..., p. 134135), a jurisdição deve atuar para acertar o fato, isto é, dizer se o réu deve ou não ser punido pelo fato cometido, e não se preocupar na resolução de um conflito intersubjetivo de vontades.

${ }^{29}$ Ibidem, p. 135.

${ }^{30}$ CORDERO, op. cit., p. 8: "Il processo penale serve a verificare se una persona debba essere punita". Tradução de Jacinto Nelson de MIRANDA COUTINHO (A lide e o conteúdo do processo penal, p. 107).

${ }^{31}$ MIRANDA COUTINHO. A lide e o conteúdo do processo penal ..., p. 107-108.

${ }^{32}$ Ibidem, p. 135.

${ }^{33}$ Vide CARNELUTTI, F. Cenerentola. Rivista di Diritto Processuale, Padova, v. 1, p. 1, p. 73-78, 1946. No Brasil, vide LOPES JR., Aury. Direito processual penal e sua conformidade constitucional. 3. ed. Rio de Janeiro: Lumen Juris, 2008, p. 30-33.

${ }^{34}$ MIRANDA COUTINHO. A lide e o conteúdo do processo penal ..., p. 142 (grifou-se). 
Processual Penal desvinculada da doutrina unitária da "teoria geral do processo".

Muito embora a nomenclatura "condições da ação" seja proveniente do processo civil, tem-se que a identificação destas no processo penal tem sido feita, na maioria das vezes, de maneira equivocada, conforme se passará a discorrer adiante.

\section{CRÍTICA À CONCEPÇÃO TRADICIONAL DAS CONDIÇÕES DA AÇÃO NO PROCESSO PENAL}

As condições da ação são os requisitos que devem estar preenchidos no momento de oferecimento da acusação, para que esta possa ser processada. ${ }^{35}$ Para que um caso penal seja acertado por um julgamento de mérito, é preciso que se preencham as condições da ação.

Há algumas questões controvertidas sobre as condições da ação na doutrina. A primeira delas se refere às ditas "teoria do binômio" ou do "trinômio". ${ }^{36}$ Tal controvérsia teve início com a indagação de Ada Pelegrini Grinover "sobre a correta ubicação das condições da ação: ou seja, integrariam elas o meritium causae ou constituiriam realmente um tertium genus, situado entre este e os pressupostos processuais?". ${ }^{37}$ Desta forma, enquanto segmentos da doutrina acreditam que as condições da ação seriam um elemento indissociável do mérito ${ }^{38}$, isto é, abraçam a teoria do binômio, ou então parcialmente autônoma, sendo algumas condições da ação Rey, 2007, p. 86.

${ }^{35}$ OLIVEIRA, Eugênio Pacelli de. Curso de processo penal. 7. ed. Belo Horizonte: Del

${ }^{36}$ NUNES DA SILVEIRA, Marco Aurélio. A tipicidade e o juízo de admissibilidade da acusação. Rio de Janeiro: Lumen Juris, 2005, p. 39-40.

${ }^{37}$ GRINOVER, Ada Pelegrini. As condições da ação penal. São Paulo: Bushatsky, 1977, p. 27.

${ }^{38}$ NUNES DA SILVEIRA, na citada obra (p. 40), traz neste sentido as posições de Giuseppe CHIOVENDA (Apud LIEBMAN, Enrico Túlio. Despacho saneador e o julgamento de mérito, p. 224) e Francisco Cavalcanti PONTES DE MIRANDA (Comentários ao Código de Processo Civil de 1939. Vol. II, p. 405). 
apenas matéria de mérito ${ }^{39}$, a maior parte da doutrina ${ }^{40}$ adota, sem restrições, a teoria do trinômio, que distingue as matérias mérito, condições da ação e pressupostos processuais. $^{41}$

Ademais, na hipótese de ausência de alguma das condições da ação, convencionou-se dizer, no âmbito do Direito Processual Civil, que o autor é carecedor de ação. Neste sentido, defendem Antonio Carlos Araújo Cintra, Ada Pelegrini Grinover e Cândido Rangel Dinamarco: "Quando faltar uma só que seja das condições da ação, diz-se que o autor é carecedor desta. Doutrinariamente há quem diga que, nessa situação, ele não tem o direito de ação (ação inexistente); e quem sustente que lhe falta o direito ao exercício desta". 42

Acredita-se, entretanto, que citados autores cometem um sério equívoco, pois entendem que as condições da ação são um limite a seu exercício. ${ }^{43}$ Ora, conforme dispõe o artigo $5^{\circ}$, inciso XXXV, da Constituição da República, a ação, enquanto direito à jurisdição, é ilimitada ${ }^{44}$, portanto não há que se falar em restrição ao exercício da ação, muito menos na inexistência de ação caso ausente uma ou mais condições da ação, pois, "sempre haverá uma sentença para declarar que tais condições não ocorrem e, dessa forma, o direito de ação estará atendido pelo julgado que declarar a inexistência das supostas condições". ${ }^{45} \mathrm{Na}$ realidade, a carência de ação ${ }^{46}$ implica uma

\footnotetext{
${ }^{39}$ LACERDA, Galeano. Despacho saneador. Porto Alegre: La Salle, 1953, p. 79

${ }^{40}$ Por todos vide LIEBMAN, Enrico Túlio. O despacho saneador e o julgamento do mérito.
} Revista Forense, Rio de Janeiro, v. 104, a. 42, f. 509, p. 225, nov. 1945; BUZAID, Alfredo. Do agravo de petição no sistema do Código de Processo Civil. 2. ed. São Paulo: Saraiva, 1956, p. 111; GRINOVER, op. cit., p. 29; MARQUES, José Frederico. Instituições de direito processual civil. 3. ed. Rio de Janeiro: Forense, 1966. v. 2, p. 38-39; TORNAGHI, Hélio Bastos. Instituições de processo penal. 2. ed. São Paulo: Saraiva, 1977. v. 1, p. 406; JARDIM, Afrânio Silva. Direito processual penal. 5. ed. Rio de Janeiro: Forense, 1995, p. 79.

${ }^{41}$ NUNES DA SILVEIRA. A tipicidade ..., p. 40.

${ }^{42}$ CINTRA et. al., op. cit., p. 260.

${ }^{43}$ Tal equívoco também se faz presente na atual redação do artigo 395 do Código de Processo Penal.

${ }^{44}$ NUNES DA SILVEIRA. A tipicidade ..., p. 41.

45 THEODORO JUNIOR, Humberto. Pressupostos processuais e condições da ação do processo cautelar. Revista Forense, Rio de Janeiro, a. 82, n. 292, p. 29, 1985. 
restrição não ao exercício da ação, mas à obtenção da tutela jurisdicional visada pelo acusador. E, neste sentido, conclui Marco Aurélio Nunes da Silveira: " (...) as condições da ação são requisitos à obtenção da tutela jurisdicional, sem uma das quais está obstada a apreciação do mérito (com o qual não se confundem), cuja finalidade é evitar o emprego abusivo do direito de ação". ${ }^{47}$

Há grande controvérsia entre a doutrina acerca de quais seriam as condições da ação no Direito Processual Penal. Hoje a ampla maioria da doutrina processual penal brasileira defende as condições da ação assim como concebidas no Direito Processual $\mathrm{Civil}^{48}$, desta forma contribuindo, em parte, para a perpetuação da malfadada "teoria geral do processo", pois universalizam a aplicação de um instituto do processo civil, entendendo-a ao processo penal. Defende-se, desta forma, a existência, no processo penal, de i) possibilidade jurídica do pedido, ii) interesse de agir e iii) legitimação ad causam. ${ }^{49}$

Com as recentes reformas do Código de Processo Penal, há intensa discussão doutrinária referente a quais seriam as condições da ação no processo penal. Isto se dá em decorrência da revogação pela Lei n. 11.719/08 do artigo 43 do Código de Processo Penal - o qual enumerava hipóteses de rejeição da peça acusatória, e do qual se extraíam as condições da ação -, bem como da nova redação dada por tal Lei ao artigo 395, inciso II, do Código - que enumera como uma das hipóteses de rejeição da acusação as "condições da ação", de forma bastante genérica, sem discriminar quais seriam estas.

Em que pese as dúvidas que hodiernamente circundam este tema, uma certeza

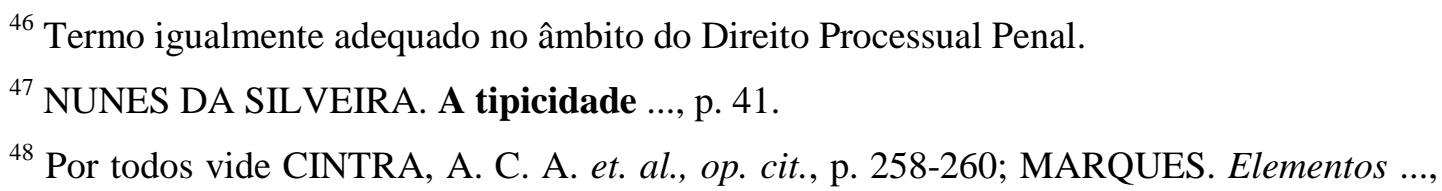
p. 292-295; TUCCI, Rogério Lauria. Teoria do direito processual penal: jurisdição, ação e processo penal (estudo sistemático). São Paulo: RT, 2003, p. 89-97; TOURINHO FILHO, Fernando da Costa. Processo penal. 24. ed. São Paulo: Saraiva, 2002. v. 1, p. 475-489; MIRABETE, Júlio Fabbrini. Processo penal. 4. ed. São Paulo: Atlas, 1995, p. 107-109; NUCCI, Guilherme de Souza. Manual de processo penal e execução penal. 3. ed. São Paulo: RT, 2007, p. 170-176; RANGEL, Paulo. Direito processual penal. 14. ed. Rio de Janeiro: Lumen Juris, 2008, p. 251-257.

${ }^{49}$ CINTRA, A. C. A. et. al., op. cit., p. 258. 
se tem: as "condições da ação" de que trata o artigo 395, inciso II, da Lei Processual Penal não são aquelas condições da ação (possibilidade jurídica do pedido, interesse de agir e legitimação ad causam) defendidas pela doutrina dita tradicional, e nem poderiam ser, pois foram pensadas para um sistema processual absolutamente diverso da realidade processual penal introduzida pelas recentes Leis n. 11.689/08 ${ }^{50}$, $11.690 / 08^{51}$ e $11.719 / 08^{52}$.

\subsection{POSSIBILIDADE JURÍDICA DO PEDIDO}

Sobre a possibilidade jurídica do pedido, Liebman a conceitua como " $a$ possibilidade para o juiz, na ordem jurídica à qual pertence, de pronunciar a espécie de decisão pedida pelo autor". ${ }^{53}$ Isto é, para que possa ser dado provimento ao pedido do autor, é necessário que seu pedido seja possível na ordem jurídica pátria. Não obtendo guarida legal o pedido formulado, o autor será carecedor de ação. Trata-se, no âmbito processual civil, de uma condição da ação estabelecida de forma negativa, conforme preceitua Egas Dirceu Moniz de Aragão:

A possibilidade jurídica [do pedido], portanto, não deve ser conceituada, como se tem feito, com vistas à existência de uma previsão no ordenamento jurídico, que torne o pedido viável em tese, mas, isto sim, com vistas à inexistência, no ordenamento jurídico, de uma previsão que o torne inviável. Se a lei contiver um tal veto, será caso de impossibilidade jurídica do pedido; faltará uma das condições da ação. ${ }^{54}$

\footnotetext{
${ }^{50}$ Reformou o procedimento dos crimes de competência do Tribunal do Júri.

${ }^{51}$ Reformou a matéria referente a prova.

${ }^{52}$ Reformou os procedimentos comuns.

${ }^{53}$ LIEBMAN, op. cit., p. 223.
}

${ }^{54}$ MONIZ DE ARAGÃO, Egas Dirceu. Comentários ao Código de Processo Civil. 3. ed. Rio de Janeiro: Forense, 1979. v. 2, p. 521. 
Isto é, segundo Jacinto Nelson de Miranda Coutinho, "não propriamente quando o ordenamento jurídico preveja, em tese, a providência, mas quando não contenha uma disposição a inviabilizá-la. Em suma, no direito processual civil, é possível o agente exercer o direito de ação sempre que o ordenamento jurídico não o vete". 55

Tal entendimento, porém, não encontra amparo no Direito Processual Penal, sendo, portanto, inaceitável tal condição da ação no processo penal, pois, conforme leciona Miranda Coutinho:

(...) o requisito, visto pelo ângulo da tipicidade - não precisa ir longe para compreender que quando o art. 43, I, do CPP fala de crime, está tratando do tipo necessariamente deve ser conceituado de modo positivo. Em outras palavras: para o autor ver procedente a ação, deve levar ao juiz, na imputação, uma conduta que, aparentemente, corresponda a um tipo legal. ${ }^{56}$

Em outras palavras, no processo penal, de modo diverso ao que ocorre no processo civil, para que a acusação possa ser processada e julgada, é imprescindível que haja previsão expressa na Lei Penal de punibilidade da conduta imputada, isto é, haja a previsão de um tipo penal que incida sobre tal conduta. Desta forma, enquanto no processo civil basta que a lei não vede o provimento jurisdicional visado pelo autor $^{57}$, no processo penal exige-se que haja expressa permissão do processamento do fato imputado como decorrência lógica do princípio da legalidade (nullum crimen nulla poena sine legem praevia, scripta, stricta et certa $^{58}{ }^{59}$ ), sendo necessário que o fato imputado na acusação seja definido como crime na Lei Penal.

${ }^{55}$ MIRANDA COUTINHO. A lide ..., p. 146. Grifou-se.

${ }^{56}$ Ibidem, loc. cit.

${ }^{57}$ Como, por exemplo, em um caso de cobrança de dívida de jogo, conforme vedação do artigo 814 do Código Civil.

${ }^{58}$ Nulo é o crime e nula é a pena sem lei prévia, escrita, estrita e certa.

${ }^{59}$ CIRINO DOS SANTOS, Juarez. Direito penal: parte geral. 3. ed. Curitiba: ICPC Lumen Juris, 2008, p. 20. 
Assim, não faz sentido se transportar o conceito processual civil para o processo penal se não se respeitar as características intrínsecas deste. Sendo necessário se alterar o ethos de sua formulação, questiona-se o porquê da adaptação do conceito, se há a possibilidade de se formular categoria própria do processo penal, referente especificamente à tipicidade.

\subsection{INTERESSE DE AGIR}

Quanto ao interesse de agir, entende a doutrina processual civil sua existência quando "há para o autor utilidade e necessidade de conseguir o recebimento de seu pedido, para obter, por êsse meio, a satisfação do interêsse (material) que ficou insatisfeito pela atitude de outra pessoa" ${ }^{60}$, isto é, o autor tem interesse na demanda quando essa lhe trouxer utilidade. ${ }^{61}$

Tal fundamento está ligado ao binômio "necessidade-adequação", pois, além da necessidade de se recorrer à tutela jurisdicional para obtenção do provimento visado, é indispensável, também, que tal provimento seja adequado à solução do litígio. ${ }^{62}$ É importante ressaltar, ademais, que o interesse de agir, ou "interesse processual", segundo Ada Pelegrini Grinover ${ }^{63}$, não se confunde com o "interesse material", pois, enquanto este diz respeito ao interesse em lide, ou interesse primário, o interesse de agir é um interesse na composição da lide, ou interesse secundário, utilizado para obter, por meio do acionamento da Justiça, a satisfação do interesse

\footnotetext{
${ }^{60}$ LIEBMAN, op. cit., p. 224.

${ }^{61}$ BADARÓ, Gustavo Henrique. Direito processual penal. Rio de Janeiro: Elsevier, 2008. t. 1, p. 69.

${ }^{62}$ CINTRA, A. C. A. et. al., op. cit., p. 223; NUNES DA SILVEIRA, M. A. O interesse de agir e sua (in)adequação ao direito processual penal. Curitiba, 2008, 203 f. Dissertação (Mestrado em Direito) - Pós-Graduação em Direito da Universidade Federal do Paraná, p. 103.

${ }^{63}$ GRINOVER, op. cit., p. 87.
} 
material. $^{64}$

Tal conceito é de todo inútil ao Direito Processual Penal, pois, em decorrência do princípio da indefectibilidade da jurisdição penal (nulla poena sine iudicio), da maneira como concebido pela doutrina monista, sempre haveria "interesse de agir" no processo penal. O "interesse de agir" estaria implícito em todas as acusações. ${ }^{65} \mathrm{Em}$ realidade, conforme leciona Nunes da Silveira:

(...) as tentativas de compatibilização empreendidas jamais alcançariam êxito pleno. Ao contrário, não raro, seus defensores lançam mão de malabarismos lingüísticos, como dizer que, eis que o processo penal é sempre necessário, esta condição da ação está implícita em toda acusação. Ora, se algo está sempre presente, por óbvio em nada contribui para o juízo de admissibilidade da acusação. O mesmo deve ser dito do interesse-adequação: a acusação é o único meio adequado à provocação da atuação jurisdicional visando o acertamento positivo do caso penal. ${ }^{66}$

Sendo o processo penal o único meio possível e necessário para a imposição de uma sanção penal ao autor de um fato punível, a ação proposta pelo Ministério Público ou pelo ofendido será sempre necessária e útil para o fim proposto, qual seja, o processamento do fato e o acertamento do caso penal, e, nos casos de acertamento positivo do caso penal - ou seja, caso se verifique a culpa do acusado -, também a cominação de pena ao imputado.

Desta forma, percebe-se que se trata de outro caso de utilização indevida de uma categoria do processo civil, sendo esta, inclusive, a posição defendida até mesmo por segmentos da doutrina monista. ${ }^{67}$ Não resta, portanto, justificativa para

\footnotetext{
${ }^{64}$ Ibidem, loc. cit.
}

${ }^{65}$ Neste sentido: GRINOVER, op. cit., p. 132; BREDA, Antônio Acir. Notas sobre o anteprojeto de Código de Processo Penal. Direito Penal. Revista dos Tribunais, São Paulo, n. 11/12, p. 58, jul./dez. 1973, p. 58; MIRANDA COUTINHO. A lide e o conteúdo do processo penal ..., p. 145-146; MOURA, Maria Thereza Rocha Assis. Justa causa para a ação penal. São Paulo: RT, 2001, p. 216-217.

\footnotetext{
${ }^{66}$ NUNES DA SILVEIRA. O interesse de agir ..., p. 182. Grifou-se.

${ }^{67}$ GRINOVER, op. cit., p. 132.
} 
manutenção do interesse de agir entre o rol das condições da ação no processo penal.

\subsection{LEGITIMAÇÃO AD CAUSAM}

Por fim, sobre a legitimação ad causam, ou "legitimação para agir", Liebman a atrela ao interesse de agir, afirmando possuir legitimação para propor ou contestar uma demanda aquele a quem pertença tal interesse, ou a quem este fizer referência. ${ }^{68}$ Assim, estaria legitimado para agir apenas aquele a quem se referir o interesse material em conflito, pois, de acordo com o artigo $6^{\circ}$ do Código de Processo Civil, "ninguém poderá pleitear, em nome próprio, direito alheio, salvo quando autorizado em lei". 69

Ora, é patente que no processo penal o representante do Ministério Público não detém a titularidade sobre o interesse material em conflito, bem como não possui qualquer tipo de pretensão: a atuação ministerial, ao menos no momento de oferecimento da peça acusatória, restringe-se a um pedido de processamento do caso por meio de juízo de admissibilidade positivo da acusação oferecida; não é correto, dada a conjuntura probatória em referida fase processual, o pedido condenatório, pois o membro do Ministério Público deve produzir provas também em favor do acusado ao longo da instrução processual. O representante do Parquet não possui, desta forma, "pretensão punitiva".

Situação semelhante ocorre nos casos de ação penal de iniciativa privada, pois o querelante, assim como o Ministério Público, não é titular do poder de punir - tal poder resta exclusivamente sobre as mãos do juiz, a quem cabe decidir sobre o acertamento, seja ele positivo ou negativo, do caso penal. Não há que se falar, portanto, em "pertinência subjetiva do interesse de agir". ${ }^{70}$

\footnotetext{
${ }^{68}$ LIEBMAN, op. cit., p. 224.

${ }^{69}$ NUNES DA SILVEIRA. O interesse de agir ..., p. 104.

${ }^{70}$ LIEBMAN, op. cit., p. 224.
} 
Não se olvida a legitimidade de parte enquanto condição da ação no processo penal. $^{71}$ Todavia o problema no âmbito processual penal é diverso daquele que se apresenta no processo civil: no processo penal cabe apenas ao juízo perquirir se o órgão acusatório é adequado à espécie de ação penal prevista em lei - ou, melhor, se é o Ministério Público quem está a oferecer a acusação nos casos de ação penal de iniciativa pública, condicionada ou incondicionada, ou se é o ofendido ou seu representante legal quem oferece a queixa nos casos em que a lei prevê ação penal de iniciativa privada.

Novamente, não há motivo para a transposição ao processo penal do conceito processual civil de "legitimação para agir", quando os escopos de tais categorias nas diferentes espécies de processo são diversos. Estando tal conceito ligado intimamente à noção de lide, não há nenhuma justificativa plausível para a sua aplicação no processo penal. $^{72}$

\section{A CONCEPÇÃO CRÍTICA DAS CONDIÇÕES DA AÇÃO COMPATÍVEL COM O PROCESSO PENAL BRASILEIRO}

Conforme se defendeu, para o (re)pensar de uma teoria geral do Direito Processual Penal, é preciso buscar categorias próprias do processo penal, evidentemente sem se descartar as contribuições úteis oriundas da teoria geral do Direito Processual Civil, mas, ressalte-se, apenas aquilo que seja verdadeiramente compatível e útil. Adaptações impossíveis e o alargamento de conceitos de nenhuma utilidade ou relevância para o Direito Processual Penal com o único propósito de se propagar uma "teoria geral do processo" não podem ser admitidos.

De acordo com a acertada lição de Cordero:

\footnotetext{
${ }^{71}$ NUNES DA SILVEIRA. O interesse de agir ..., p. 111.

${ }^{72}$ Ibidem, p. 112.
} 
Lembre-se ainda que, para os cultores do processo civil, a ação, por antonomásia, é o poder de provocar uma decisão de mérito; e, assim, diz-se que é desprovido de ação quem invoca um provimento de conteúdo juridicamente impossível ou não é legitimado ou não tem interesse de agir. Conceitos do gênero não podem ser transpostos ao processo penal. ${ }^{73}$

Também comunga desta opinião Maria Thereza Rocha de Assis Moura:

Concluímos, da análise das denominadas condições da ação, ser de todo desaconselhável e impróprio, tecnicamente, transferir o entendimento existente no Direito Processual Civil para o Direito Processual Penal. Tais como definidas as condições naquele ramo do Direito, não se ajustam ao processo penal. Inútil querer ignorar o jurista, a martelo, as evidentes diferenças existentes entre as duas disciplinas, para ver operar na ação penal condenatória as três condições da ação, tal como divisadas no processo civil. ${ }^{74}$

Acredita-se ter sido equivocada a opção legislativa pela supressão do artigo 43 do Código de Processo Penal, pois este era o único dispositivo legal do qual se podia extrair concretamente as causas de rejeição da peça acusatória, e não termos genéricos e abstratos como faz o artigo 395, em sua nova redação. A última reforma pelo qual passou o Código de Processo Penal retirou qualquer resquício de sistematicidade que nele ainda poderia ser encontrado.

Em realidade, as condições da ação para o processo penal devem (ou deveriam) ser entendidas como as causas que historicamente obstaram o recebimento da denúncia ou queixa pelo órgão jurisdicional ${ }^{75}$, consequentemente impedindo o acertamento do caso penal visado pelo acusador em situações teratológicas, sem que haja qualquer plausibilidade da peça acusatória, tais como: i) a ausência de previsão legal de punibilidade do(s) fato(s) narrado(s) na lei penal, ii) a incidência de

${ }^{73}$ CORDERO, op. cit., p. 35. Tradução de Marco Aurélio NUNES DA SILVEIRA ( $O$ interesse de agir e sua (in)adequação ao Direito Processual Penal, p. 107). Note-se, apenas, que a posição retratada pelo autor italiano é tida hoje por ultrapassada pela doutrina processual civil moderna, porém a crítica é relevante se destinada aos propagadores do pensamento liebmaniano.

\footnotetext{
${ }^{74}$ MOURA, op. cit., p. 215.

${ }^{75}$ LOPES JR., op. cit., p. 336.
} 
causa extintiva da punibilidade do imputado; iii) a propositura da acusação pelo Ministério Público em caso de ação penal de iniciativa pública, condicionada ou não, ou pelo particular, em caso de ação penal de iniciativa privada; iv) a ausência de fundamentos informativos (certeza quanto à materialidade do fato e indícios suficientes de autoria) que embasem a acusação, conforme o artigo 18 do Código de Processo Penal, traduzida como a "justa causa", que encontra previsão legal no inciso III do artigo 395 de citado diploma legal.

\subsection{TIPICIDADE APARENTE}

Em primeiro lugar, ao dispor o artigo 43, inciso I, do Código de Processo Penal que "[A denúncia ou queixa será rejeitada quando:] o fato narrado evidentemente não constituir crime", estava o legislador a se referir à hipótese de não descrever a imputação feita na peça acusatória um fato que a lei penal defina como crime, ou seja, constitua um fato típico. ${ }^{76}$

O problema, neste ponto, é definir até onde deve ir o juízo cognitivo da tipicidade na análise de admissibilidade da peça acusatória, isto é, se deveria integrar o exame da tipicidade seus elementos negativos ${ }^{77}$, ou não. Não obstante doutrinadores de gabarito $^{78}$ entendam pela necessidade do juízo sobre a tipicidade incluir os elementos negativos do tipo, acredita-se que o que deve ser analisado no juízo de admissibilidade da peça acusatória é estritamente a tipicidade aparente. ${ }^{79}$

Ensina Miranda Coutinho que "uma coisa (...) é o autor demonstrar que os

${ }^{76}$ Sobre a tipicidade, vide CIRINO DOS SANTOS, op. cit., p. 105-110.

${ }^{77}$ MACHADO, Luiz Alberto. Direito criminal: parte geral. São Paulo: RT, 1987, p. 90-91.

${ }^{78}$ Por todos, vide LOPES JR, op. cit., p. 337-339.

${ }^{79}$ MIRANDA COUTINHO. A lide e o conteúdo do processo penal ..., p. 146-148. NUNES DA SILVEIRA. A tipicidade e o juízo de admissibilidade da acusação ..., p. 57. GEBRAN NETO, João Pedro. Inquérito policial: arquivamento e princípio da obrigatoriedade. Curitiba: Juruá, 1996, p. 47-48. 
fatos narrados na imputação têm, na aparência, credibilidade suficiente para serem considerados típicos, algo tão-somente comprovável no curso do processo; outra, é a comprovação efetiva". ${ }^{80}$

Desta forma, não há como se exigir do órgão acusatório que este demonstre cabalmente a tipicidade do fato, até porque se trata de matéria que será provada no curso da instrução criminal. Ademais, caso entenda o julgador a efetiva comprovação da tipicidade nesta fase preliminar, não haveria como se reconhecer posteriormente sua inexistência.

Assim, entende-se que no juízo de admissibilidade da acusação, a fim de se evitar um prejulgamento do mérito do processo, a cognição da tipicidade deve se dar de forma bastante sumária, cabendo ao julgador verificar tão somente a aparência de tipicidade dos fatos narrados, isto é, se o fato narrado na peça acusatória está previsto na legislação penal brasileira como crime.

Mesmo com a supressão do artigo 43 do Código de Processo Penal pela recente Lei n. 11.719/08, entende-se necessária a análise da tipicidade aparente enquanto condição da ação, pois é imponderável um juízo de admissibilidade positivo em caso de cristalina atipicidade. Tal condição da ação decorre logicamente do princípio da reserva legal, "pois somente aquelas as condutas que se amoldem a descrição legal é que podem estar sujeitos à sanção previamente estabelecida em lei ${ }^{81}$ Conforme entendimento de Miranda Coutinho:

(...) não há como afastar a tipicidade do juízo de admissibilidade da acusação. Excluí-la pode significar uma ainda maior desumanização de um processo penal como o nosso, que nunca foi muito humano. $\mathrm{O}$ dia-a-dia do fórum ensina o quanto um processo penal faz o réu sofrer. É necessário não esquecer este detalhe. ${ }^{82}$

\footnotetext{
${ }^{80}$ MIRANDA COUTINHO. A lide e o conteúdo do processo penal ..., p. 147.

${ }^{81}$ GEBRAN NETO, op. cit., p. 47.

${ }^{82}$ MIRANDA COUTINHO. A lide e o conteúdo do processo penal ..., p. 148.
} 


\subsection{PUNIBILIDADE CONCRETA}

Em seguida, segundo a redação do revogado artigo 43, inciso II, do Código de Processo Penal "[A denúncia ou queixa será rejeitada quando:] já estiver extinta a punibilidade pela prescrição ou outra causa". Segundo tal dispositivo, o legislador tratou de impedir expressamente que fossem instaurados processos para o acertamento de casos penais em que já tivesse se operado a extinção da punibilidade. ${ }^{83}$

Estando o processo penal voltado ao acertamento de casos penais, e visa, em casos de acertamento positivo, à aplicação de sanção criminal, parece um tanto quanto absurda a possibilidade de recebimento de uma peça acusatória que impute ao denunciado fato, por exemplo, prescrito.

Portanto, a fim de se garantir a aplicação da pena em caso de acertamento positivo do caso penal, criou o legislador a figura da punibilidade concreta como condição da ação, pois, para que se faça juízo de admissibilidade positivo de uma acusação, é necessário que ao menos se vislumbre a possibilidade de se aplicar

punição criminal ao acusado, caso condenado. ${ }^{84}$ Portanto, no juízo de admissibilidade da acusação, o julgador deve perquirir a real possibilidade de aplicação da sanção criminal ao final do processo, não tendo se configurado nenhuma das circunstâncias do artigo 107 do Código Penal.

Nas palavras de João Pedro Gebran Neto: “É exatamente por isso que a punibilidade concreta é uma das condições da ação penal, pois, sem ela, o fim último do processo não será atingido". 85

Evidentemente, tal condição da ação se refere apenas às causas extintivas de

${ }^{83}$ Sobre a extinção da punibilidade vide SÁNCHEZ RIOS, Rodrigo. Das causas de extinção da punibilidade nos delitos econômicos. São Paulo: RT, 2003. 58

${ }^{84}$ NUNES DA SILVEIRA. A tipicidade e o juízo de admissibilidade da acusação ..., p.

${ }^{85}$ GEBRAN NETO, op. cit., p. 49. 
punibilidade existentes antes do oferecimento da acusação. ${ }^{86}$ Caso sobrevenha ao longo do curso do processo causa de extinção da punibilidade, esta deverá ser reconhecida a qualquer tempo, segundo a inteligência do artigo 61 do Código de Processo Penal. ${ }^{87}$

Desta forma, mesmo tendo sido revogado o artigo 43 do Código de Processo Penal e seu inciso II, ainda persiste motivo para a manutenção da punibilidade concreta dentre o rol de condições da ação penal. Afinal, parece insustentável a instauração de um processo em que já se tenha operado uma causa de extinção da punibilidade.

Ademais, em que pese o artigo 397, inciso IV, do Código de Processo Penal faça menção à extinção da punibilidade como causa de absolvição sumária do acusado, tem-se que este é novo equívoco cometido pela Lei n. 11.719/08, pois extinção da punibilidade, como se sabe, é matéria referente ao mérito, que faz coisa julgada ${ }^{88}$, e que pode ser reconhecida pelo julgador a qualquer tempo, em qualquer estágio que se encontre o processo, não podendo, assim, ser restrita a uma causa de "absolvição sumária", que só pode ser conhecida na fase processual prevista no artigo 397 da lei processual penal.

Além disto, até mesmo por se tratar de questão de ordem pública ${ }^{89}$, tendo operado causa extintiva de punibilidade, o processo não poderia ter se iniciado, segundo o artigo 396 do Código de Processo Penal, pois a denúncia ou queixa sequer deveriam ser recebidas. O reconhecimento da extinção da punibilidade, caso já tenha operado, não pode ocorrer após a instauração do processo. Isto não parece algo lógico.

\footnotetext{
${ }^{86}$ Ibidem, loc. cit.
}

${ }^{87}$ Ibidem, loc. cit.

${ }^{88}$ MIRANDA COUTINHO, J. N. A natureza cautelar da decisão de arquivamento do inquérito policial. Revista de Processo, São Paulo, a. 18, n. 70, p. 50, abr./jun. 1993.

${ }^{89}$ As normas de ordem pública "são aquelas que respeitam a toda a sociedade, mais do que a cidadãos individualmente considerados; aquelas que se inspiram no bem comum, mais do que nos interesses de alguns" (CRUZ E TUCCI, José Rogério; TUCCI, Rogério Lauria. Constituição de 1998 e processo: regramentos e garantias constitucionais do processo. São Paulo: Saraiva, 1989, p. 83). 


\subsection{LEGITIMIDADE DE PARTE}

Outra condição da ação poderia ser encontrada na letra do artigo 43, inciso III, primeira parte, ("[A denúncia ou queixa será rejeitada quando:] for manifesta a ilegitimidade de parte (...)"), segundo o qual só poderia ser recebida a ação caso essa fosse oferecida pela parte legítima.

Neste caso, para o processo penal, surge a relevância da legitimidade de parte em decorrência da dicotomia entre ação penal pública e privada. ${ }^{90}$ Desta forma, seria legítimo para o oferecimento da ação o Ministério Público nos casos de ação penal de iniciativa pública, tanto condicionada quanto incondicionada, pois assim está disposto no artigo 129, inciso I, da Constituição Federal, tratando-se, inclusive, de competência privativa sua. Já nos casos de ação penal de iniciativa privada, por força do artigo 30 do Código de Processo Penal, esta só poderá ser intentada pelo ofendido ou seu representante legal.

Assim, acredita-se que a legitimidade de parte, por ter ainda grande valor para o processo penal, persiste entre as condições da ação penal, pois não se imagina possível uma acusação deduzida por parte manifestamente ilegítima ser recebida e processada.

Tal condição da ação, porém, tende a desaparecer com a futura reforma do Código de Processo Penal proposta pela comissão externa de juristas do Senado Federal $^{91}$, que tem como uma das principais propostas a extinção das ações penais de iniciativa privada, tornando o exercício da ação penal exclusivo do Ministério Público. $^{92}$

\footnotetext{
${ }^{90}$ GEBRAN NETO, op. cit., p. 50.

${ }^{91}$ Vide <http://www.senado.gov.br/novocpp>.

${ }^{92}$ DEDA, Rhodrigo. Comissão quer tornar mais rígido o controle de grampos. Gazeta do
} Povo, Curitiba, a. 91, n. 28.988, 20 mar. 2006, p. 14. Caderno Vida e Cidadania. 


\subsection{LASTRO MÍNIMO INFORMATIVO ("JUSTA CAUSA”)}

A Lei n. 11.719/08, ao pretensamente definir as condições da ação, aparentou dar à "justa causa" tratamento jurídico diverso, pois assim dispõe a nova redação do artigo 395:

Art. 395. A denúncia ou queixa será rejeitada quando:

I-for manifestamente inepta;

II - faltar pressuposto processual ou condição para o exercício da ação penal;

III - faltar justa causa para o exercício da ação penal. ${ }^{93}$

Todavia, não é isso o que ocorre na prática. Em que pese a lei processual penal fale em limite ao "exercício da ação penal", já se demonstrou que, na realidade, o que as condições da ação limitam é a obtenção de tutela jurisdicional por meio da ação, pois deve-se ter em vista que o exercício da ação, enquanto direito à jurisdição, é ilimitado segundo a Constituição da República. ${ }^{94}$ Trata-se de imprecisão terminológica da Lei.

Não obstante, a "justa causa" é, de fato, um limite à obtenção da tutela jurisdicional, portanto é uma das condições da ação penal.

Segundo a melhor doutrina ${ }^{95}$, a "justa causa" pode ser compreendida de acordo com o artigo 18 do Código de Processo Penal, o qual narra "Depois de ordenado o arquivamento do inquérito pela autoridade judiciária, por falta de base para a denúncia, a autoridade policial poderá proceder a outras pesquisas, se de outras provas tiver notícia". ${ }^{96}$ Compreende-se, assim, que a acusação será rejeitada caso não existam informações suficientes para embasá-la.

\footnotetext{
${ }^{93}$ Grifou-se.

${ }^{94}$ NUNES DA SILVEIRA. A tipicidade e o juízo de admissibilidade ..., p. 41.

95 BREDA, Antônio Acir. Efeitos da declaração de nulidade no processo penal. MP,
} Curitiba, a. 9, n. 9, p. 177-178, 1980. MIRANDA COUTINHO. A lide e o conteúdo do processo penal ..., p. 145. NUNES DA SILVEIRA. A tipicidade e o juízo de admissibilidade ..., p. 60. GEBRAN NETO, op. cit., p. 51-58. LOPES JR, op. cit., p. 343.

${ }^{96}$ Grifou-se. 
Conforme o magistério de Antonio Acir Breda:

(...) faltará condição para o exercício da ação penal, nos casos que o titular do ius puniendi pedir o arquivamento "por falta de base para a denúncia". Estaríamos diante da chamada falta de justa causa para a acusação, isto é, falta de prova do fato e de indícios de autoria, requisitos indispensáveis ao exercício da ação penal, uma vez que o processo penal não se compadece com a acusação fruto de mera elaboração mental. ${ }^{97}$

Portanto, a fim de se assegurar a integridade da acusação, é necessário, para o seu recebimento, que seja oferecida em conjunto com um lastro mínimo informativo ${ }^{98}$ capaz de embasar as imputações feitas, o que se traduz em "existência de prova do fato e indícios de autoria". 99

Ousa-se, neste ponto, discordar do magistério de consagrados autores paranaenses $^{100}$ ao definir a quarta e última condição da ação, pois se entende ser o significante "justa causa" categoria por demais abrangente e indeterminada, capaz de acolher inúmeros significados, nos mais variados ramos do direito. ${ }^{101}$ Prefere-se, assim, a utilização da denominação "lastro mínimo informativo", por a entender mais adequado para abarcar o conteúdo desta condição da ação, muito embora a Lei Processual Penal também utilize o vocábulo "justa causa".

Ressalta-se, por fim, que durante a análise de existência de lastro mínimo

${ }^{97}$ BREDA. Efeitos da declaração ..., p. 178. Grifou-se.

${ }^{98}$ JARDIM, op. cit., p. 80. Muito embora o processualista carioca se referira a um "lastro mínimo probatório", se entende o vocábulo utilizado de forma incorreta, pois até o início do processo penal não há provas - estas só existem após a incidência do crivo do contraditório. Até então, o que existem são apenas informações obtidas ao longo da investigação preliminar.

${ }^{99}$ NUNES DA SILVEIRA. A tipicidade e o juízo de admissibilidade ..., p. 60. Novamente aqui se entende criticável a eleição do vocábulo "prova" pelo autor. O que deve haver, em realidade, é a certeza quanto à existência do fato imputado obtida por meio das informações colhidas ao longo da investigação preliminar, e não "prova do fato".

${ }^{100}$ BREDA. Efeitos da declaração ..., p. 177-178. MIRANDA COUTINHO. A lide e o conteúdo do processo penal ..., p. 145. NUNES DA SILVEIRA. A tipicidade e o juízo de admissibilidade da acusação ..., p. 60. GEBRAN NETO, op. cit., p. 51-58.

${ }^{101}$ MOURA, op. cit., p. 97-118. 
informativo da peça acusatória não se deve adentrar em análise minuciosa do injusto penal, pois isto é matéria a ser analisada pelo julgador ao proferir a sentença. O que deve ser analisado é apenas a existência de informações na investigação preliminar que possibilitem a formação de um juízo de certeza acerca da existência do fato narrado e suas circunstâncias, bem como a indicação de que o sujeito denunciado ou querelado seja $\mathrm{o}$ autor deste fato.

\section{CONCLUSÃO}

Percebe-se, desta forma, que em realidade a estrutura até então conhecida no que tange as condições da ação penal em muito pouco mudou, em que pese as mudanças legislativas trazidas pela Lei n. 11.719/08.

As condições da ação no processo penal permanecem sendo aquelas identificadas pela doutrina emancipadora da Teoria Geral do Processo Penal, quais sejam, tipicidade aparente, punibilidade concreta, legitimidade de parte e justa causa, pois as condições da ação tratadas pela doutrina processual civil e monista são de todo inadequadas à realidade processual penal.

Ressalte-se que o presente estudo não tem a pretensão de encerrar as discussões acerca das condições da ação penal. Ao contrário, busca apenas incitar o debate sobre o tema, bem como fornecer algum tipo de saída para aqueles que ainda não se encontram satisfeitos com os comentários até o momento editados sobre a reforma do Código de Processo Penal. 


\section{REFERÊNCIAS}

BADARÓ, Gustavo Henrique. Direito processual penal. Rio de Janeiro: Elsevier, 2008. t. 1.

BREDA, Antônio Acir. Efeitos da declaração de nulidade no processo penal. MP, Curitiba, a. 9, n. 9, p. 171-189, 1980.

. Notas sobre o anteprojeto de Código de Processo Penal. Direito Penal. Revista dos Tribunais, São Paulo, n. 11/12, p. 49-74, jul./dez. 1973.

BUZAID, Alfredo. Do agravo de petição no sistema do Código de Processo Civil. 2. ed. São Paulo: Saraiva, 1956.

CALAMANDREI, Piero. Il concetto di "lite" nel pensiero di Francesco Carnelutti. Rivista di Diritto Processuale Civile, Padova, v. 5, p. 1, p. 3-22, 1928.

CARNELUTTI, Francesco. Ancora sulla lite nel processo penale (Postilla). Rivista di Diritto Processuale Civile, Padova, v. 7, p. 1, p. 245-248, 1930.

Cenerentola. Rivista di Diritto Processuale, Padova, v. 1, p. 1, p. 73-78, 1946.

Lezioni di diritto processuale civile. Padova: Cedam, 1926. v. 1.

CINTRA, Antonio Carlos de Araújo; GRINOVER, Ada Pelegrini; DINAMARCO, Cândido Rangel. Teoria geral do processo. 18. ed. São Paulo: Malheiros, 2002.

CIRINO DOS SANTOS, Juarez. Direito penal: parte geral. 3. ed. Curitiba: ICPC Lumen Juris, 2008.

CORDERO, Franco. Procedura penale. Milano: Giuffré, 1987.

CRUZ E TUCCI, José Rogério; TUCCI, Rogério Lauria. Constituição de 1998 e processo: regramentos e garantias constitucionais do processo. São Paulo: Saraiva, 1989.

DALIA, Andréa Antonio; FERRAIOLI, Marzia. Manuale di diritto processuale penale. 6. ed. Padova: Cedam, 2006.

DEDA, Rhodrigo. Comissão quer tornar mais rígido o controle de grampos. Gazeta do Povo, Curitiba, a. 91, n. 28.988, 20 mar. 2006, p. 14. Caderno Vida e Cidadania.

FOWLER, Fernando Newton Bittencourt. Anotações em torno da ação penal pública no projeto de reforma. MP, Curitiba, a. 6, n. 7, p. 81-101, 1977.

GEBRAN NETO, João Pedro. Inquérito policial: arquivamento e princípio da 
obrigatoriedade. Curitiba: Juruá, 1996.

GRINOVER, Ada Pelegrini. As condições da ação penal. São Paulo: Bushatsky, 1977.

INVREA, Franceso. La servitù del giudicato. Rivista di Diritto Processuale Civile, Padova, v. 7, p. 1, p. 223-244, 1930.

JARDIM, Afrânio Silva. Direito processual penal. 5. ed. Rio de Janeiro: Forense, 1995.

LACERDA, Galeano. Despacho saneador. Porto Alegre: La Salle, 1953.

LIEBMAN, Enrico Túlio. O despacho saneador e o julgamento do mérito. Revista Forense, Rio de Janeiro, v. 104, a. 42, f. 509, p. 216-226, nov. 1945.

LOPES JR., Aury. Direito processual penal e sua conformidade constitucional. 3. ed. Rio de Janeiro: Lumen Juris, 2008.

MACHADO, Luiz Alberto. Direito criminal: parte geral. São Paulo: RT, 1987.

MARQUES, José Frederico. Elementos de direito processual penal. Campinas: Bookseller, 1997. v. 2.

v. 2 .

Instituições de direito processual civil. 3. ed. Rio de Janeiro: Forense, 1966.

MIRABETE, Júlio Fabbrini. Processo penal. 4. ed. São Paulo: Atlas, 1995.

MIRANDA COUTINHO, Jacinto Nelson de. A lide e o conteúdo do processo penal. Curitiba: Juruá, 1989.

. A natureza cautelar da decisão de arquivamento do inquérito policial. Revista de Processo, São Paulo, a. 18, n. 70, p. 49-58, abr./jun. 1993.

O papel do novo juiz no processo penal. In: (Coord.). Crítica à teoria geral do direito processual penal. Rio de Janeiro: Renovar, 2001. p. 3-55.

MONIZ DE ARAGÃO, Egas Dirceu. Comentários ao Código de Processo Civil. 3. ed. Rio de Janeiro: Forense, 1979. v. 2.

MOURA, Maria Thereza Rocha Assis. Justa causa para a ação penal. São Paulo: RT, 2001.

NUCCI, Guilherme de Souza. Manual de processo penal e execução penal. 3. ed. São Paulo: RT, 2007.

NUNES DA SILVEIRA, Marco Aurélio. A tipicidade e o juízo de admissibilidade 
da acusação. Rio de Janeiro: Lumen Juris, 2005.

$O$ interesse de agir e sua (in)adequação ao direito processual penal. Curitiba, 2008, 203 f. Dissertação (Mestrado em Direito) - Pós-Graduação em Direito da Universidade Federal do Paraná.

OLIVEIRA, Eugênio Pacelli de. Curso de processo penal. 7. ed. Belo Horizonte: Del Rey, 2007.

PAOLI, Giulio. La nozione di lite nel processo penale. Rivista di Diritto Processuale Civile, Padova, v. 7, p. 1, p. 63-74, 1930.

PONTES DE MIRANDA, Francisco Cavalcanti. Comentários ao Código de Processo Civil de 1939. 2. ed. Rio de Janeiro: Forense, 1960. v. 2.

RANGEL, Paulo. Direito processual penal. 14. ed. Rio de Janeiro: Lumen Juris, 2008 .

SÁNCHEZ RIOS, Rodrigo. Das causas de extinção da punibilidade nos delitos econômicos. São Paulo: RT, 2003.

THEODORO JUNIOR, Humberto. Pressupostos processuais e condições da ação do processo cautelar. Revista Forense, Rio de Janeiro, a. 82, n. 292, p. 19-29, 1985.

TORNAGHI, Hélio Bastos. Instituições de processo penal. 2. ed. São Paulo: Saraiva, 1977. v. 1.

TOURINHO FILHO, Fernando da Costa. Processo penal. 24. ed. São Paulo: Saraiva, 2002. v. 1.

TUCCI, Rogério Lauria. Teoria do direito processual penal: jurisdição, ação e processo penal (estudo sistemático). São Paulo: RT, 2003. 